English Language and Linguistics, 26.1:1-26. C The Author(s), 2021. Published by Cambridge University Press. This is an Open Access article, distributed under the terms of the Creative Commons Attribution licence (http://creativecommons.org/licenses/by/4.0/), which permits unrestricted re-use, distribution, and reproduction in any medium, provided the original work is properly cited.

doi:10.1017/S1360674320000465

\title{
Old Norse-derived lexis in multilingual accounts: a case study
}

\author{
A MANDA ROIG-MARÍN \\ University of Cambridge \\ (Received 25 July 2020; revised 2 November 2020)
}

\begin{abstract}
This article on Old Norse represents a fundamental departure from the previous literature on loaned material by examining multilingual documents written in Medieval Latin rather than in monolingual English, namely the Durham Account Rolls (DAR). The potential of this richer and more complex interplay between languages will be further addressed throughout the article, which assesses the different kinds of evidence available for establishing the relative plausibility for a word being derived from ON. Dance's $(2013,2018,2019)$ taxonomy will be discussed and applied to multilingual material for the first time. The article concludes with some notes on the main semantic fields to which ON-derived lexis contributed within the multilingual lexical networks of the $D A R$.
\end{abstract}

Keywords: lexical borrowing, Old Norse-derived lexis, medieval multilingualism

\section{Introduction}

\subsection{Some notes on Anglo-Scandinavian contact in medieval England}

The effects of the contact between speakers of Old English (OE) and Old Norse $(\mathrm{ON})^{1}$ in early medieval England still continue to fascinate researchers and the general public alike. The nature of the bilingual environment and culture that arose out of the continuous exchanges (linguistic and otherwise) between the newcomers and the native population are of extraordinary singularity in the history of English: the genetic proximity between $\mathrm{ON}$ and $\mathrm{OE}$ means that these two languages shared a significant number of cognates apart from evincing formal similarities. That is why a certain degree of mutual intelligibility has often been assumed (see, among others, Townend (2002) and Dance (2012) and the references therein) and the absorption of a large number of loanwords

\footnotetext{
${ }^{1}$ Durkin (2014: 175) makes use of the term 'early Scandinavian' - also found in the Oxford English Dictionary, 3rd edition (OED; 1990-) - and explains how 'Old Norse' is terminologically imprecise in the context of Anglo-Scandinavian contact in the British Isles since English came into contact with the linguistic ancestors of both West Norse (Norwegian (henceforth, Norw) and Icelandic (Icel)) and East Norse (Danish (Dan) and Swedish (Sw)). The differences between the two varieties, however, were not sufficiently noticeable as to be able to further distinguish West from East Norse input in English, which is why I will avail myself of the long-standing term of Old Norse (ON).
} 
was facilitated. The most prototypical scenario for lexical borrowing involves requiring a new word to express a newly 'imported' concept or extralinguistic reality previously non-existent in the receiving community. In contrast to these 'need-based' loans, there was a transfer of material at a much deeper level: some prepositions and the third-person plural pronouns are argued to have been borrowed from $\mathrm{ON}$ - see Cole (2018) for an alternative, language-internal, explanation for some forms of them - and native word forms took senses or meanings from Norse (e.g. dream). Only a situation of intense contact would have possibly catalysed the borrowing of such fundamental lexical units in a language, a phenomenon which would have derived, in Dance's words (2013: 43), from 'source-language-led "imposition" in communities routinely code-switching from Old Norse into Old English'. Yet the scarcity of firm evidence has often led some authors to reassess the role of contact-induced change in the explanation of linguistic change on a lexical and morphosyntactic level. Lass (1997: 209) would argue that 'in the absence of evidence, an endogenous explanation of a phenomenon is more parsimonious, because endogenous change must occur in any case, whereas borrowing is never necessary'. The World Loanword Database (Haspelmath \& Tadmoor 2009a, 2009b), the largest compilation of cross-linguistic data available to explore lexical borrowing, has proven that the borrowing of core vocabulary is unexpectedly common, and that limitations on the kinds and degree of material subject to be borrowed between closely related languages are particularly elusive (cf. Haspelmath \& Tadmoor 2009a, 2009b; Dance 2019: I.27). Regardless of our epistemological inclination, this finding should make us problematise Liberman's assertion that 'all other conditions being equal, tracing a word to a native root should be preferred to declaring it a borrowing' (2008: xxvi). Contact can also be invoked in conjunction with potential native developments - which might have been actualised or accelerated because of the influence of the other language - so a scholarly polarisation between the advocates of internal vs external explanations for language change is not particularly helpful when thinking about multilingual scenarios; nor is the preference for language-internal accounts tantamount to dismissing any form of Scandinavian influence: from a lexical viewpoint, there has been general consensus on some fairly secure borrowings from Norse. Yet some aforementioned factors such as the typological proximity between the two languages and the paucity of textual witnesses means that 'it is often impossible to be sure whether borrowing or endogenous change is at work' (Dance 2019: I.29). Alluring as the Viking element has been ever since the nineteenth century, as Dance (2019) points out, in etymological research few directions have been given as to how to decide whether a particular lexeme exhibits ON influence when the amount (or lack) of information available can be utilised to argue both ways. The extent to which we should rely on negative evidence, that is, on unrecorded OE cognates, has divided scholars. Kolb (1965: 133) suggests not searching for such cognates too eagerly, whereas other authors embrace Norse input even if earlier native words (with the same meaning) are attested (see, e.g., Ringe 2004). Dance's (2013, 2018, 2019) rigorous typology will be utilised in the present article. 


\subsection{Aims, methodology and textual material}

This article on Old Norse represents a fundamental departure from the previous literature on loaned material by examining sources written in Medieval Latin (ML) rather than in monolingual English: the Extracts from the Account Rolls of the Abbey of Durham from the Original MSS [1278-1538], edited by Fowler in three volumes (1898-1901) and which I collated with the original manuscripts held at Durham Cathedral Library Archives. ${ }^{2}$ Fowler's three-volume work is one of the largest edited collections of multilingual texts produced in Latin, ${ }^{3}$ so it represents an ideal testing ground for the study of the influence of $\mathrm{ON}$-derived lexis in texts which have not been interrogated from this perspective until now. Since the $D A R$ are not like any other monolingual texts in Middle English (ME) and usually exhibit a certain degree of technicality, partly inherent to the nature of record-keeping itself, the vocabulary that surfaces in this material has an extra dimension of relevance in the multilingual context of late medieval and early modern England. ${ }^{4}$ The potential of this richer and more complex interplay between languages will be further discussed throughout this article, but for now it is worth stressing that the taxonomical principles that underlie this examination are common to ME-based studies. I will, therefore, be drawing on classic reference works on ON-derived loanwords in medieval English such as Björkman's (1900-2) monograph and more recent research such as that carried out for the Gersum project (Dance, Pons-Sanz \& Schorn 2019).

In order to examine the Norse element in the $D A R$, I shall briefly revisit some of the main criteria and kinds of evidence adduced for ON borrowings in the literature. In particular, Dance's $(2013,2018,2019)$ typology and underlying theoretical basis and discussion will be followed. Important early contributions cited in Björkman's seminal work include Coleridge (1859), Steenstrup (1882), Skeat (1882), Brate (1885) and Kluge (1901). Björkman (1900) assesses the reliability and scope of his predecessors, ${ }^{5}$ while foregrounding their treatment of $\mathrm{ON}$ borrowings, primarily on phonological grounds (see, e.g., Brate 1885: 4-30; Knigge 1885: 71-2). Coleridge (1859: 26) made use of a word's distribution in the Germanic languages, and Björkman (1900) himself concentrated on phonological tests but also considered other (less reliable) criteria. Dance propounds a twofold classification for the kinds of positive evidence that tends to be used for assessing Scandinavian input: 'structural' and 'circumstantial' evidence. Under structural evidence fall aspects relating to the formal structure of the language

\footnotetext{
2 My archival visit to the Durham Cathedral Archives was funded by the AHRC (award no. AH/L503897/1), whose support is here gratefully acknowledged.

3 See Wright's extensive work on unedited multilingual material of this kind, which she calls 'mixed-language writing' (Wright 1992, 1995, 1998, 2002, 2010, 2011, 2012, 2017), as well as Trotter (2000, 2003, 2009, 2010) for their discussion of the main three languages of late medieval England, Anglo-French (AF), Medieval Latin (ML) and Middle English (ME) in a business or administrative context (see also Ingham (2009) and Roig-Marín (forthcoming a) on the specific context of the $D A R$ ).

4 There is no observable diachronic variation in the use of ON-derived lexis in the DAR.

${ }^{5}$ Björkman (1900) also acknowledges the primary historical interest in Anglo-Scandinavian relationships that characterised Steenstrup's work in contrast to Brate's (1885) philological research.
} 
(e.g. phonology and morphology); and circumstantial evidence would 'derive from patterns of occurrence' (Dance 2019: I.36). He clarifies that chronology is not a reason per se for assigning ON influence; rather, the lateness of a word (900 is the terminus post quem for any visible lexical effect of Anglo-Scandinavian contact on written OE) is a prerequisite for a loan; attestations of lexemes earlier than the tenth century are deemed cognates, not loans. I will review in greater depth Dance's classification of evidence, which is primarily arranged into four main types (Types A, B, C and D), and I will illustrate each type with examples from the database. Broadly speaking, Type A relies on regular, formal evidence (phonology (A1), morphology (A2), and both phonology and morphology (A3)) to identify ON input. Type B signals that the Germanic root is not recorded in OE before Anglo-Scandinavian contact, so it examines the recorded use of that root across Germanic (Gmc) languages: the stem may be known only in North Germanic (NGmc) (B1) or in other Gmc languages as well (B2). In contrast, under Type $\mathrm{C}$ are lexical items which are indeed attested in the early, pre-contact, OE period, but an aspect of that lexeme (its derivational form (C1), orthographic/phonological form (C2), meaning (C3), the formation of a compound/ phrase (C4), or frequency (C5)) suggests ON influence. Finally, Type D indicates uncertainty: the etymology of the form may be problematic (D1) or the interpretation of the lexeme may be unclear in its Middle English (ME) textual environment (details of each type and subtype will be provided later in this article).

The lexis that is the focus of this article is a small part of a larger database of 1,598 lexical items (not counting orthographic variants of the same item) which were manually culled from the edited DAR. These rolls correspond to several departments: volume 1 comprises excerpts from the Cellarers', Hostillers', Almoners' (elemosinaria), Chamberlains' and Infirmarers' (magistrorum infirmarie) Rolls; volume 2, Commoners', Terrars', Stock-keepers', Sacrists', Feretrars', Bursars' Rolls and Marescalcia Prioris; and volume 3, Bursars' and Miners' Rolls. There are also some short extracts from Treasurers' books (1569-80) and miscellanea (1293-1542), mostly in monolingual English, which were beyond the scope of my research. All the ON-derived lexis here discussed is, therefore, attested in the rolls produced in ML. The Appendix lists all the spelling and morphological variants of the words in the DAR which are discussed in the body of the text. ${ }^{6}$ The presence of the plural-forming suffix -ez in ON-derived lexis (e.g. crosez, flaggez, skelez, stopez) is rather common and may make us wonder whether the data herein analysed can be interpreted as Middle English or Anglo-French. Within the larger context of the $D A R$, where a variety of morphemes $(-i s /-y s,-e s,-e z$, or the zero morpheme plural) is used, my contention is that $-e z$ is part of a large translingual repertoire that was available to scribes and that all these morphemes were used non-distinctively in multilingual texts, regardless of the etymological origin of the word. ${ }^{7}$

6 The order of appearance of the occurrences in the Appendix mirrors the one in the edited rolls.

${ }^{7}$ Owing to space constraints, I will not elaborate on this point, but it will be addressed in greater detail in my forthcoming research. 
The DAR material comes from an area beyond Samuels's 'Great Scandinavian Belt ${ }^{\text {' }}$ (1985: 269), so, in theory, a relatively lower incidence of ON influence should surface. A total of 160 lexical items (67 simplexes and 93 complex lexical units) have been tentatively classified as evincing $\mathrm{ON}$ influx (c. $10 \%$ of the total number of $D A R$ vernacular items, although, out of that percentage, only c. $30 \%$ of them can be deemed rather secure (Type A) borrowings from $\mathrm{ON}$ ). How representative this figure can be in the context of a text traditionally classified as 'Latin', in which there are few closed-class lexemes coming from the vernaculars (a few prepositions and the definite article from French), ${ }^{9}$ is a question that remains to be answered in future research. For the purposes of this article, rather than analysing $\mathrm{ON}$ influence on the language of the $D A R$ in purely numerical terms, I carried out a qualitative analysis. Many of these lexemes are classified under the $\mathrm{ON}$-influenced headwords, so that any compounds/ lexical units are not counted as distinct lemmas. Other tentative borrowings were not included in the list because the evidence was either too tenuous (e.g. in capestonys ${ }^{10}$ 'the top stones' (cf. the OED ((1893), s.v. cope, n. $\left.\left.{ }^{1}\right)\right)^{11}$ 'the Middle English forms might be from ON kápa, but this is an unlikely source') or it was suggested in the past but was ruled out (e.g. step in stepled 'a vessel/cauldron for soaking [something]', where the $O E D$ ((1916), s.v. steep, v. $\left.{ }^{1}\right)$ indicates that it is 'of difficult etymology' and discards the possibility of it being a loanword from ON (Old Icelandic (OIcel) støypa) on phonological grounds). ${ }^{12}$ The direct etymon is the main focus of investigation and, therefore, words such as til 'a cut of meat' and wyndas 'windlass' have been excluded from this list on the basis of their direct borrowing from French (even if they were ultimately borrowed from ON). So was brusket' (also bruskett') 'the brisket or breast of an animal': the $O E D$ identifies formal and semantic resemblances between brusket' and French brechet, whereas the Middle English Dictionary (MED) only considers its alleged NGmc parallels (OIcel brjósk 'cartilage', Danish (Dan) brusk). Palatalisation in the syllabic onset position is expected in Central French dialects (in contrast to the Insular variety), so it is more likely that brusket' comes from Anglo-French. The information provided by the $O E D$ and the $M E D$ has been collated with that included in Dance's volume 2 (2019) and the Gersum database, which also gives the proposed $\mathrm{ON}$ etymon, the OE cognate (if any), and phonological and morphological markers (if relevant). All of the terms in this article are regularly attested in ME.

While there might be discrepancies between the main etymologies given in the $O E D$ and the $M E D$, some items do not attract much controversy. The classification below,

\footnotetext{
${ }^{8}$ See Samuels (1985: 269) on the Great Scandinavian Belt, 'excluding the old kingdom of Bernicia in Durham and Northumberland'.

9 See Roig-Marín (forthcoming a) and the references therein for an overview of the use of the French definite article in this kind of multilingual text.

${ }^{10}$ Only the first attestation in the DAR editions is here given. Capital letters are preserved as rendered in the editions unless the word is also attested in lower case, in which case the latter variant is preferred.

11 It is worth stressing that the $O E D$ is, in Durkin's words (2016: 392), a 'dynamically changing resource', which means that I will be citing the date of publication/revision for each headword used.

12 As per common practice, I will cite the OIcel reflexes as etyma of the ON loans.
} 
nevertheless, is subject to further refinements. I have not made use of Dance's 'probability categories' - unless they are adopted from the Gersum project or Dance (2019) - but have indicated if the evidence for a tentative $\mathrm{ON}$ borrowing can be reinforced by the dialectal distribution of that particular word through the use of the letter 'c' (mainly confined to the north or east of England in the general ME lexis) or, just in one instance, ' $b$ ' (confined to the north or east in the toponymic record). The final section of this article considers the prevalent view on the semantic nature of ON-derived lexis in English and the specificities of the $D A R$ data.

\section{A taxonomy of ON-derived lexis}

\subsection{Type $A$}

Systematic phonological and morphological parameters are well established in the literature as regular and reliable. ${ }^{13}$ Indeed, as Dance puts it, "their consistency is what allows comparative philologists to argue for English and Norse as distinct developments on the Gmc family tree in the first place' (2019: I.39). Dance further subdivides Type A borrowings into three subcategories: A1 phonological criteria, A2 morphological criteria, and A3 phonological and morphological criteria. A paradigmatic example of these formal, phonological, correspondences is OE /a:/ (corresponding to $\mathrm{ME} / \mathrm{a}$ :, o:/) and $\mathrm{ON} / \mathrm{ei} /{ }^{14}$ If the English form happens to exhibit the corresponding ON sound instead of the expected OE-derived form, this would be indicative of a discontinuity between $\mathrm{OE}$ and $\mathrm{ME}$ generated by contact with $\mathrm{ON}$. The OE cognate is, nevertheless, not needed to prove the influx of Old Norse precisely because of the systematicity of these - in this case, phonological - features. The probability of a native variant developing independently so that it would eventually converge with the $\mathrm{ON}$ form often seems unlikely; hence, we can speak of relatively 'secure' criteria within the philological paradigm. Yet, if there are no attested cognates in other Germanic languages apart from Old Norse, the distinctiveness of allegedly ON features may be at stake, and the possibility of independent convergence gains ground. ${ }^{15}$ Unfortunately, there is only one instance of the A2 class in the DAR: the presence of the inflectional - $t$ in twhertsawes 'crosscut saws'; $t$ is the suffix attached to adjectives to form adverbs in ON but not in OE: OIcel pvert adverb 'across', originally neuter of the OIcel adjective $p v e r-r=$ OE pwerh (cf. OED (1912) thwart, adv., prep. and adj.). There are none representing A3, which is why I shall concentrate on the A1 group.

13 See Lass (1997: 123-39) on the need to establish correspondences which are "lawful", statable in principle as particular instantiations of general rules'.

14 The fronting and raising of OE /a:/ in northern Middle English is accounted for in Roig-Marín (forthcoming b), focusing on northern Middle English spelling evidence in the $D A R$. It equally addresses the use of $<$ ai $>$ and $<$ ay $>$ for reflexes of OE /a:/ in northern late Middle English (see below).

15 Dance (2019: I.42) cites mynne, rake and rasse, among other examples of vocabulary which did not make the cut in this sense and are, therefore, classified as Type D. 
Our understanding of certain phonological changes (A1) has been considerably refined since the nineteenth century, so that not all of them are regarded as equally reliable - at least, under all circumstances - in present-day scholarship. Absence of palatalisation is a traditional index of $\mathrm{ON}$ influence. It had been long assumed that palatalisation had not been fully operative in Northumbrian, or that in initial position $/ \mathrm{k} / \mathrm{did}$ not assibilate. $^{16}$ This belief, implying northern-exclusive developments, has been progressively invalidated ever since Gevenich (1918) proved prevalent $/ \mathrm{k} />/ \mathrm{t} /$ in native northern toponyms. Yet its absence in non-initial position is much more problematic and is often seen as a possible native development, which is why in this article more secure - initial-position - environments will be considered. The reflex of PGmc (Proto-Germanic) */k/ is $/ \mathrm{t} /$ in Old English but not in $\mathrm{ON}$, as can be seen in castyng 'in ploughing, the method and operation of turning all the furrow-slices of a ridge in one direction, and those of the adjoining ridge in the opposite direction' (OED (1889), s.v. casting, n. 1.d.), cf. OIcel kasta, replacing the native OE weorpan in ME (Gersum, s.v. kest); kerr (Gersum, s.v. ker [A1bc] - not in OE); keruyngknyves 'carving-knives' (OIcel kyrfa, OE cyrf); kydsape 'soap for treating sheep-louse' (OIcel kið); and kyrn 'a churn', a northern variant of OE cyrne, probably influenced by contact with ON (OIcel kirna). The other contexts in which we can perform a palatalisation test are $\mathrm{PGmc} * / \mathrm{g} />\mathrm{ON} / \mathrm{g} /, \mathrm{OE} / \mathrm{j} /$ and $\mathrm{PGmc} * / \mathrm{sk} /$ which also remains $/ \mathrm{sk} /$ in $\mathrm{ON}$ but palatalises in $\mathrm{OE}$, resulting in $\mathrm{ME} / \mathrm{J} /$. Gersuma 'a manorial rent' $(<\mathrm{OE}$ garsama < OIcel gørsimi) and the garth ('yard') compounds (OIcel garð-r): bernegarth, connyngarth $(\times 2)$, ympgarth, swynhousgarth, stakgarth $(\times 3)$ and Wodegarth exhibit $\mathrm{ON} / \mathrm{g} /{ }^{17}$ It is worth noting that the native variant, with yard, is also present in three compounds, ymppeyard $(\times 2)$, Wodyard $(\times 5)$ and Hempyard. Both the native and the $\mathrm{ON}$-influenced variants mostly occur in the fourteenth century, so there does not seem to be a diachronic motivation for the use of one form over another, especially in the cases of ymppeyard and Wodyard; rather, it is lexically conditioned. Sponegarn 'yarn produced by the process of spinning' (pronounced with $/ \mathrm{g} /$ ) also seems to exhibit partial input from $\mathrm{ON}$ (cf. OE gearn), and there is further evidence for the absence of palatalisation in the following lexemes starting with $<\mathrm{sc} / \mathrm{sk}>$ : e.g. skelez 'vessels' (OIcel skjōla) $(\times 7 ; \times 1$ with $<\mathrm{sc}>),{ }^{18}$ scale (pl.) 'scales', also in merowscales, Weyscill (all of them always spelt with $<\mathrm{sc}>$ ), ${ }^{19}$ scappes, also skepe (OIcel skeppa)

${ }^{16}$ For a general description of palatalisation, see, inter alia, Campbell (1959: §§426-41), Hogg (1992: §§7.15-43) and Jordan-Crook (1974: $\S \S 177-94)$, and on its outcomes, Luick (1935), West (1936), Penzl (1947), Watson (1947), Kristensson (1976), Hogg (1979), Cercignani (1983), Krygier (2000), Minkova (2003, 2014, 2016), Dance (2003: 141-2, 2012, 2013, 2018, 2019: I.§8) and Liberman (2007).

17 There is no evidence in the $D A R$ for the $<\mathrm{g}>$ being pronounced as a palatal consonant in this phonological environment - that is, before an $<\mathrm{a}>-$ in Germanic-origin vocabulary (e.g. in gabelarum 'of the gables (of a building)' gaveloc 'an iron crowbar', gang 'a set', consistently spelled with $<\mathrm{g}>$ ).

18 The total number of occurrences of a lexical unit is given here in parentheses regardless of the spelling variants in which it can be found.

19 The $<$ sk $>$ in scale is not favoured despite the possible confusion with the word scalis (coming from CL) 'ladders' although the plural-forming suffix -ez (and less often, -es) is employed instead of -is, so this was perhaps a strategy to distinguish the two words in case it was used. 
$(\times 7)$, sker and may skynnes. Scale (p1.), skelez and scappes are also in the Dictionary of Medieval Latin from British Sources (henceforth, DMLBS) (cf. DMLBS, s.v. 2 scala, skela and skeppa). Regarding the last two, skelez and scappes, they are written with $<\mathrm{sk}>$ and $<$ sc $>$ (see the Appendix for all the spelling variants recorded in the DAR), the former spelling allegedly representing an adapted Latinised version (nonetheless present in $\mathrm{ME}$ as well) and the latter being a reflex of the source etymon, directly adopted. These two graphemic versions are in ML as well as in ME. ${ }^{20}$ Skelez is also spelt with $<$ sch $>$ (the spelling variant that the $M E D$ cites as northern '(N) schele' only because it is in the DAR, s.v. skẹle (n.)) in the records of the DMLBS (schalis and schelis with vowel alternation too), which evidences the flexibility of Medieval Latin. It might be contended that the early instances of these words were 'unadapted' and, therefore, contain $<$ sk $>$ and, as time progressed, $<\mathrm{sc}>$ replaced $<$ sk $>$ in ML texts. Wright (1998, 2012) suggests the reverse phenomenon in the context of multilingual business writing which would show a progressive 'Anglicisation' of the lexis before there was a complete shift to monolingual English. The scarce $<$ sk $>$ data in the $D A R$ prevent me from reaching any generalising conclusions, but the DMLBS shows considerable variation across space, time and possibly genre, rather than a steady trend (e.g. see skippis ((Ac. Milton) DCCant) as early as 1299 and skepcis (Househ. Bk. Durh. 133) from 1532).

Other consonant features evincing ON influence are the following: PGmc */ठ/>ON/ð/ in girthys 'hoops of iron/wood for a barrel' $(\times 20)$, girthbukyls $(\times 7)$, Girthwebbs $(\times 9)$ and Girthetres $(\times 1, \mathrm{~A} 1 \mathrm{c}$ in Gersum, s.v. gerrethis), cp. OIcel gjor $\delta<\mathrm{PGmc} *$ gerđō, and there are no attested forms containing a fricative in West Germanic languages (cf. e.g. Middle Dutch (MDut) gherde); ON consonant assimilation in broddis 'nails' (ON brodd- $r=\mathrm{OE}$ brord), also in brodnales, latbrodes, latbroddes, Sponbrod, stanbrod $(\times 5)$ and Strabrod, and in gonnys $(\times 5)$ (cf. OIcel gunnr vs OE gūp, the latter with loss of the nasal consonant and compensatory lengthening (Gersum, s.v. gunnes)); male 'payment' in landmall $(\times 3)$, landmalebok (le) and medowmale, a lexeme which exhibits loss of the interdental fricative present in the Old English cognate тжељel 'discussion, meeting'; the sense of the English lexeme (which survived only in Scots and northern English dialects) seems to be closer to the OI derivative máli 'stipulation, contract, stipulated pay' (cf. OED (2000) s.v. mail, n.1); and PGmc*/jj/ and */ww/ > ON /ggj/ and /ggw/ by sharpening or Holtzmann's Law, a regular (albeit obscure) change in Gothic and ON, yielding ME $/ \mathrm{g} /$ in byghern (OE beew 'barley') and eggs in Rent Egges $(\times 3)$ 'eggs used as rent payment' $(\mathrm{OE}$ ćg). This change is not found in $\mathrm{OE}$, which is why the equivalent $\mathrm{OE}$ and ME forms have vowels, semi-vowels or diphthongs. Likewise, lyttynglede $(\times 2)$ 'a dyeing tank' can be accounted for by referring to $\mathrm{PGmc} * / \mathrm{w} /$, which was lost before /1/ in ON but remained in OE wlite 'beauty, splendour, appearance' (OED (1928), s.v. $\dagger$ wlite, $\mathrm{n}$.).

${ }^{20}$ MED, s.v. scōle n.(1): 'Also skole, (N [Northern]) schole \& (early) skale, (early SWM [Southwest Midland]) scale, (early SW [Southwest]) scoale \& (error) stole; s.v. skep(pe (n.) Also skepe, scep (pe, schep (pe, szepe \& skip (pe, skipe, scippe; s.v. skẹle n. Also (N) schele \& (error) skliyee'. 
Another consonantal change which may be more problematic in etymological descriptions is $\mathrm{ON}$ assimilation of $/ \mathrm{nk} />/ \mathrm{kk} /$ in drawkyng 'saturating quicklime with water'. According to the $O E D$ ((1897), s.v. drawk, v.), it should, in theory, be ascribed to Type D1 since its etymology is 'obscure', only 'possibly' related to ON (OIcel drekkja < PGmc *drankian 'to drawn') 'drench, drown, swamp, submerge'; yet, given the Northern English / Scottish distribution of the word (cf. the Dictionary of the Older Scottish Tongue [DOST], s.v. Drawk, v.; lemma not in the MED), the lack of a native source and/or closer Germanic etymon with this sense and phonological make-up, we can place it within this group.

A number of vocalic features can also be used as diagnostic tests in the DAR material: ON /عi/vs OE /a:/, visible in ploughswaynlandes (OIcel sveinn = OE swān) 'lands designated to and cultivated by ploughmen', ${ }^{21}$ and $\mathrm{PGmc} * / \mathrm{au} />\mathrm{ON} / \mathrm{au} /, / \mathrm{ou} /$, in windowclathe 'a window curtain' and stopez $(\times 4)$, also as stowpys $(\times 3)$ 'buckets or jars for liquids (also as a measure)' (ON staup = OE stéap). Influence of the $\mathrm{ON}$ vowel is patent in strabrod 'a wooden pin used in fastening thatch' (OIcel strá= OE stréaw (PGmc. *strawo-)).

\subsection{Types $B, C$ and $D$}

The following types of evidence can be classified as less secure because they do not rely on formal criteria like Type A. The ultimate lexical source for these items is here the determining factor: the form source may not be attested in early OE but recorded in ON (in which case, the word would belong to Type B); it may also be found in early OE (Type C); or the form source may be obscure, not unequivocally identifiable (Type D). Generally speaking, the scale of probability ranges from the more secure Type B1 words to the unclear Type D items, but within these major groupings, there is also scope for a spectrum of individual cases, which may be equally placed on a continuum of likelihood as far as ON input is concerned (hence, the numeric subclassification).

\subsubsection{Type B}

An underlying premise with Type B words is that if a particular Germanic root is not recorded in early written $\mathrm{OE}$, it may signify that it did not survive long enough to explain its use post Anglo-Norse contact. Frequency of use might play a part in a word's attestation, meaning that very specialised or low-frequency items might be absent in extant OE writings, but this should be carefully assessed on a case-by-case basis. A further distinction can be made between Type B1 (when the root is only known in

21 Swayn is always derived from Old Norse in the literature (see Gersum, s.v. swaynes and the references therein), but it is worth acknowledging that etymological/a:/ could also be graphemically represented as $<$ ai $>$ and $<$ ay $>$ in late northern Middle English (see Roig-Marín (forthcoming b) for details and its problematisation). Yet the $<$ ai $>/<$ ay $>$ digraphic spelling of swayn is by no means unique to the north of England and it is in fact attested in the first half of the fourteenth century (thus, earlier than the proposed dating of this innovation in the north) in such texts as The Metrical Chronicle of Robert of Gloucester (c.1325 (c.1300) Glo.Chron.A (Clg A.11)), whose Linguistic atlas of late mediaeval English (LALME) linguistic profile locates it to Gloucs., in the south-west of England (see MED, s.v. swein and its other attestations). 
NGmc) and Type B2 items (when these lexemes are indeed present in Gothic and/or the continental West Gmc languages). The information has been mostly gleaned from both the $O E D$ and $M E D$, but the classification below is not exclusively reliant on the $M E D$ or the $O E D$ entries, some of which are still in the process of being revised and do not give enough details or may wrongly assume that a given lexeme unproblematically comes from $\mathrm{ON}$.

Some examples of Type B1 are eldyngpan 'fuelling' (cf. OIcel elding, Dan ilding), hale 'handles of a plough' (OIcel hali, Dan hale 'tail'); rove 'a small metal plate' (OIcel ró, Norwegian (Norw) ro, Faroese rógv), whose further etymology is unknown (possibly related to the Germanic stem wro 'crooked object' 'curvature' (OED (2011), s.v. rove, n.1)); muk 'manure' in mukforkez $(\times 2)$ and mukhak $(\times 3)$ which, before ME, is only extant in late OE outside the North Germanic languages (cf. Gersum, s.v. mokke (B1)); and toft 'the land on which a house stands' (cf. Old Swedish (Sw) tompt, Norw tomt and Dan tomt). The etymologies of brakennez and Kelinges $(\times 4)$ are more challenging although they certainly seem to be B1: there is no surviving form for brakennez 'ferns' in ON although it is reconstructed as *brakni on the basis of Scandinavian equivalents in Danish, Swedish, Icelandic and Norwegian; no OE *broecen is recorded either (cf. Gersum, s.v. braken, n. (B1c)). ${ }^{22}$ The origin of Kelinges is likewise uncertain: the OED ((1901) s.v. keeling, n.1) suggests that the name 'like cod n.3, seems to be confined to English, but may be ultimately related to Icelandic keila "gadus longus", or to Dan kolle, kuller, Sw kolja "haddock", and the MED agrees on the possibility of representing a borrowing from $\mathrm{ON}$ (OIcel keila). ${ }^{23}$

Lexical items belonging to Type B2 are, among others, dam 'a dam' a common Germanic root in Old Frisian (OFris) dam, dom, MDut and Middle Low German (MLG) dam(m), Middle High German (MHG) tam and OIcel dammr (fourteenthfifteenth cent.), ${ }^{24}$ flakes $(\times 4)^{25}$ 'hurdles' (OIcel flake, fleke, MDut vlāke, MLG flake), gabelorum $(\times 8)$ 'gables (also a façade) of a building', the closest comparanda are OIceI gafl, OSw gafl, ODan -gawel although there is an ablaut variant of the stem in MDut gevel, Old High German (OHG) gibili (also with a different suffix OHG gebal) and MHG gibel. Anglo-French possibly reinforced the spellings with $<\mathrm{b}>$ (given under the $\beta$ forms in the $O E D)$, so gable received multiple partial inputs $(O E D$ (2018), s.v. gable, n. ${ }^{1}$ ); crokez 'tools of hooked form' $(\times 9)^{26}$ is in ON (OIcel krókr) and seems to

${ }^{22}$ It is classified as 'c' in Gersum because the $M E D$ attestations are mostly from the north and the East Midlands (MED, s.v. brāke(n (n.)).

23 Irish ceilliuin and Gaelic cilean seem to be borrowings of the ME word themselves (cf. OED (1901), s.v. keeling, n.1). The word was certainly northern during the ME period.

${ }^{24}$ In the Gersum database (s.v. dam), it is labelled as BBB2abc. Dance's letter-based taxonomy and the subclassification into 'probability categories' attempts to further clarify the degree to which researchers can ascribe $\mathrm{ON}$ influence to a particular lexeme. In the case of Type B, B represents fairly general consensus on the status of the word as deriving from $\mathrm{ON}$; BB involves some disagreement, since other alternatives to $\mathrm{ON}$ input may be likely; and BBB words may be explained more satisfactorily through other explanations.

25 Also in scaffalde flakes, chesefleke and Cartfleykke.

${ }^{26}$ Crook with the $<\mathrm{u}>$ spelling variant $(\times 5)$, also in brercroke $(\mathrm{BB} 2 \mathrm{~b})$, dorecrokez, fleshcruk $(\times 2)$ and Shepecroke $(\times 2)$. 
be part of the same ablaut series (krak-, krôk) as OHG kracko, krahho 'hook'; it is commonly derived from the $\mathrm{ON}$ etymon rather than $\mathrm{OE} * c r \bar{k} k$ (here departing from the $M E D$, s.v. crộk n.) or OE crycc 'crutch, staff', which might also be related to the aforementioned ablaut series (also see Gersum, s.v. crokez n. (pl.) (BB2b)), ${ }^{27}$ tedyr 'tether' (< ON tjóðr; cf. OIcel tjóður), which corresponds to West Fris tyader, tieder (fifteenth cent.), MLG/MDut tûder, tudder and LG tüder, tüdder, töder, tider, tier, tir; and ryvyng 'splitting or cleaving of wood' (OIcel rifa, Norwegian rive, OSw riva, ODan rywa) is also cognate with OFris -rivva in ütrivva 'tear up' (OED (2010), s.v. riving, n.1).

Less straightforward B2 lexical items (nevertheless, probably ON-derived) are kagges, Ripp's and snypys. Kagges in the DAR has to be read as 'kegs', 'small casks or barrels', thereby fully corresponding to ON kaggi. Nonetheless, there seem to be cognates in Dutch kaag, Low German kag with the meaning of 'fishing-boats'. That word was also borrowed into French (cague 'fishing-boat' and caque 'a herring-barrel'), so the theory that 'ships, or boats, and casks, or tubs, often go by the same name' is echoed in the $O E D$ etymology of the word ((1888), s.v. $\left.\dagger \mathrm{cag}, \mathrm{n}^{1}{ }^{1}\right)$, which is relatively uncertain (the $M E D$ just limits its etymology to give the ON etymon but does not mention any possible cognates in other Germanic languages), so the word is tentatively included here. Ripp's 'baskets for fish' is 'probably' cognate, according to the OED ((2010), s.v. rip, n. $\left.{ }^{1}\right)$, with German regional (Low German) rep, OHG href, ref 'basket' (MHG ref, German (now regional) Reff 'pannier'). The $O E D$ also draws attention to the lack of additional supporting evidence by means of the word's regional distribution, since 'the (post-medieval) currency of the word in south-eastern counties outside the Danelaw area is surprising in a word of Scandinavian origin'. The development of lexemes throughout time can be varied and complex, so this can only be taken as a lexicographical curiosity. Snypys 'snipes' has an even more complicated origin: the $O E D$ links it to $\mathrm{ON}$, but the lexeme seems only to be attested as part of compounds (Icel mýrisnípa, Norw myr-, strandsnipa) and the connections with MLG and LG (also older Danish) snippe/ sneppe, German dialect schnippe, MDut sneppe (Dutch snep), OHG snepha (snepfa) and snepho are not clear. Yet, because the word is not found in OE and the localised attestations in the MED suggest a northern/east midland distribution, it is included here rather than along with the etymologically obscure Type D words.

\subsubsection{Type $C$}

Type $\mathrm{C}$ items vary greatly in so far as an early $\mathrm{OE}$ source form has been identified; the revealing feature is a sense, usage or word form which might be rare or unparalleled in earlier OE. Type $\mathrm{C}$ items are, therefore, classified according to that defining characteristic, which can fall under the following linguistic levels or parameters: derivational morphology (C1), phonology (C2), semantics (C3), complex word-formation processes (C4) and frequency (C5), arranged by category below.

\footnotetext{
27 Note the $O E D$ claims that it is 'unknown elsewhere in Germanic' although it does cite the possible connection to the ablaut series to which OHG kracko belongs (cf. OED (1893), s.v. crook, n. and adj.).
} 
Within Type $\mathrm{C}$ are also those lexical items whose (direct or indirect) source forms come from another language (e.g. Latin or French). The question is, again, whether the feature under consideration could be tentatively explained through an unattested (endogenous) descent or through a direct borrowing from that third language rather than from $\mathrm{ON}$, a probability that may vary widely from item to item.

Bonesilver, croceloft, flyttyng, the deverbal noun hyngynges, slawters $(\times 2)$ (also in Slawghterhouse $(\times 6)$, Slaughtermanhous $(\times 4)$ ) and wandes (also in Wandepenys and Saylwandis) are Type $\mathrm{C} 1$ and shall also be discussed in greater detail:

- OIcel bón 'boon' and OE bēn 'request, prayer' represent the only known Germanic reflexes of *bōn-. The OIcel non-mutated form may be an alternative $\bar{o}$-stem, rather than $i$-stem, development (cf. Gersum, s.v. bone, which also mentions its widespread use in ME).

- Similarly, the OE $i$-mutated form lyft contrasts with OIcel loft (lopt) $(<$ PGmc *luft-a-n) in croceloft 'a rood loft or room'; the only possibility for explaining the closer alignment of the ME (and late OE) form with the Scandinavian paradigm other than through derivation - which is to date the most authoritative account - is to assume that there was an unrecorded/now lost OE variant which had the $o$-stem (see Pons-Sanz 2013: 72-3 and Dance 2019: II.123, who classifies lofte as C1b (CC3ab));

- flyttyng 'removing' is a weak verb deriving from the root*flut-which is only recorded in NGmc (Gersum, s.v. flitt, gives the source for *flut-, the Gmc strong verb *fleutan-, with a different sense, 'float, stream', whose reflexes are OIcel fljóta, OEflèotan, OFris flìata, OHG fliozan and Old Saxon fliotan);

- ME hengen in hyngynges ('an ornamental hanging for a room, hall, etc.') was formed on PGmc *xang-. OE had the strong (VII) verb hōn (trans.) and the weak 2 hangian (intrans.), both meaning 'to hang', and nominal formations on the $i$-mutated stem, heng-, are also recorded. There are also weak 1 verbs in West Germanic languages (MDut hengen, OHG ir-henken, OFris hingia), so OE *hengan, as suggested in Gersum (s.v. henge), would be within the realms of possibility. However, the absence of recorded usage in $\mathrm{OE}$ and its northern distribution in ME has led scholars to believe it is a loanword from ON (cp. ON hęngja (weak 1 verb (trans.)), being entered in Gersum as CClac;

- for slawters 'slaughters' (OIcel slátr) there are no corresponding stems with $r$ in other Germanic languages, only OE slieht, sloeht, sleaht, sleht, sliht, slyht $<\mathrm{PGmc}$ *slaxt-(see also Gersum, s.v. slaztir);

- lastly, wandes 'rods or laths' is cross-linguistically represented in other Germanic languages (e.g. both OIcel vondr 'wand, switch' and Gothic wandus 'rod') which descend from a common root, PGmc *wanðuz, a formation on *wenðan 'to turn' (see Dance (2019: II.138) and Gersum, s.v. wandez, a lexical item entered under C1c).

There are two Type $\mathrm{C} 2$ lexical items in the $D A R$ which could be claimed to have arisen endogenously: cart and stoth. Cart (in Cartbod. (×2), Cartfleykkes, Carth'neys $(\times 3)$, cartrapes ( $\times 5)$, Cartesadle, $(\times 2)$, cartsadiltrees, cartsilver, Cartstrakes, Langcart', Stankart (le)) with metathesis $(<$ PGmc *kratt-) is not present in OE (croet) or other 
West Germanic cognates (e.g. OHG kratto). As stated in the Gersum database (Gersum, s.v. kart (labelled CC2)) and the $O E D$ ((1888), s.v. cart, n.), there is no overlap of the metathesised and unmetathesised variants, and the unmetathesised form is not attested in ME, which may be revealing in assessing the extent to which ON could have influenced (not necessarily replaced) the native form. On the other hand, in stothes 'ornamental studs' - also in dorestothez $(\times 3)$ - there is final-position $/ \delta /$ rather than $/ \mathrm{d} /$. Nonetheless, unlike girthys (Type A1, discussed above), there is a cognate in OE, so the word could have been a variant of the native studu, perhaps reinforced by ON, rather than a direct borrowing (OIcel stoð). The fact that most attestations of stooth are located to the north and east midlands is, again, not sufficient proof.

Type C3 lexical items (coddis, thyxtyll, mosse, ferybote and spon (in sponbrod and sponyarn) $),{ }^{28}$ based on semantics, are sometimes more slippery: spon represents a relatively secure Type C3 item because OE spón only had the sense of 'chip', not the utensil; coddis 'bolsters or bearings of an axle' may have had an OE source codd 'bag' and/or OIcel near-cognate koddi 'pillow'. The MED identifies sense 4, both 'a metal "cushion", such as a bearing of an axle or a bell' (4b) and, more generally, 'a pillow' (4a) as only northern (MED, s.v. $\operatorname{cod}$ n.(1)), and the $O E D$ devotes a separate entry to this northern usage $\left(O E D(1891)\right.$, s.v. cod, n. $\left.{ }^{2}\right)$, although it is noted that it shares its root with cod, $\mathrm{n}$. ' 'bag'. The connection between 'a bag' and a pillow - being a stuffed bag - becomes patent, but the fact that ON koddi (also Old Dan kodde) had the primary meaning of 'pillow' might have triggered semantic narrowing and the development of that particular sub-sense in the English lexeme; thyxtyll 'a kind of ax', in thyxtyll goug, probably comes from OI pexla (cf. Norw teksla, Dan teksel, with the same meaning in $\mathrm{OHG}$ dehsala), since it has a cognate in $\mathrm{OE}(\mathrm{OE} p \bar{\imath} x l)$ but with a different meaning 'beam or pole' (MED, s.v. thixel $\mathrm{n}$.); ${ }^{29}$ likewise, the double sense of mosse $(\times 3)$ is linked to ON (OIcel mosi both 'moss' and 'bog, moorland') since it seems that OE mos only meant 'bog' (Gersum, s.v. mosse (CCC3ab); Dance 2019: II.\$259). It has been claimed that both meanings might have already had currency in early OE, so a native-only historical trajectory is also possible; and fery in ferybote is another instance of partial multiple inputs: it is, in part, a borrowing from Scandinavian (OIcel ferja, OSw feria, ODan fcerie, all meaning 'ferry boat') as well as the outcome of the conversion of the verb ferry 'to transport or carry' (ferian in OE and OSax, and on the more specific sense of 'by boat', see OIcel ferja, Gothic farjan, and MLG veren, MHG vern) into a noun.

Bollez was tentatively included as Class $\mathrm{C} 3 \mathrm{c}$ although it is a more dubious case: bollez $(\times 2)$ is used as a term for a dry measure in the north of England and Scotland, so it was hypothesised that this sense might derive from ON (OIcel bolli) rather than OE bolla

28 Spon 'shingle' in Sponbrod 'a nail for fastening shingles' is a much less likely loan from ON: it is classified as a 'CCC3' word (see below and Dance (2019: II.\$263) s.v. sponez 'spoons' (CCC3a)), so the likelihood of it being derived from $\mathrm{ON}$ is very low.

${ }^{29}$ Unlike the $M E D$, the $O E D$ ((1912), s.v. thixel $\mid$ thixle, n.) mentions that no cognate in OE is recorded: 'known c1300, not yet found in Old English'. 
'bowl', but the argumentation seems to rest on its northern distribution (OED (1887), s.v. boll, $\mathrm{n}^{2}$ ). The closest sense recorded in the Dictionary of Old Norse Prose is 'liquid measure, measuring cup of specific size' (ONP, s.v. bolli sb. m., sense I.2) whereas in the Dictionary of Old English (DOE) no measure-related meanings are attested. Because of the highly unspecific and broad nature of terms such as bolle 'cup' (also the content of the vessel, etc.), this sense could have been developed in parallel to ON, where its usage seems to be more limited to 'liquid measures'.

$\mathrm{C} 4$ and $\mathrm{C} 5$ are represented by only two lexical items and one respectively: (C4) axiltre $(\times 6)$ and blandcorne and (C5) crosez. For the Type $\mathrm{C} 4$ stems there is a ME compound or combining form which is not in early OE although it has parallels in Scandinavian languages: the native equivalent to axiltree 'an axletree' (only recorded from early ME onwards) is axtree (OED (1885), s.v. † ax-tree, n.). Because axil was also in $\mathrm{OE}$ (OE eaxl), ${ }^{30}$ there might have lexical substitution through contact with ON (cf. the OIcel compound öxul-trē). Blandcorne is attested in Scandinavian languages, both as a simplex and as a compound, OIcel bland 'mixture' and dialectally in Swedish, blandkorn (MED, s.v. bland-corn n. 'ON; cp. Swed. dial. blandkorn \& E dial. (Yks.) blend-corn.'). There are also OE cognates bland and gebland, but, as Dance (2019: II.230) acknowledges, these OE stems are 'rare and confined to poetry', so its use in blandcorne could be tentatively derived from ON (also note this is consistent with circumstantial evidence of type ' $c$ ' for both axiltre and blandcorne). Crosez is classified as 'FC5b' (Dance 2019: II.§292; Gersum, s.v. cros): both the late OE cros (exclusively attested in the toponymic records) and ME cross have Latin crux as their ultimate etymons, but the direct source forms are less well-established; there are two possible sources, Old Irish cros and OIcel kross, and there are other cognates in AF and ML (crosce, crosse and cros, respectively) which might also have contributed to the development of the ME word if they are not borrowings of the ME lexeme themselves. Apart from the hypothesis of multiple inputs, Dance (2003: 417-18; 2019: II.246-7) and Durkin (2014: §4.1 n. 6), among others, are more inclined towards accepting the less complex explanation, which is to assume that there is just one source 'a Hiberno-Norse word borrowed from OIr cros' (Dance 2019: II.247, see also the extensive bibliography on this word listed under fn. 955).

\subsubsection{Type D}

The etymologies of Type D items are the most difficult to track down of the four categories. They are often classified as 'obscure' or 'difficult' in two main respects: the etymology of the word has not been agreed upon, although its form and sense are relatively clear (Type D1), or even the interpretation of the word in context can be highly debatable (Type D2). Type D1 is represented in the DAR by cloukis, sowmys and steyned clothes: cloukis, most likely, 'clutches', is a word with a complex history (OED (1891), s.v. clutch, n.1): the word is first attested in ME (clōke) and Scots

30 Axil in axilnayl (also in axillyng) has been discarded because the root axil seems to descend from OE eaxl rather than the ON form (OIcel öxl). 
(clüke), and only in the seventeenth century do there seem to be records of a Southern palatalised version (clooch). The reconstructed OE stem would have been *clōc, clōce or, alternatively, ${ }^{*} c l \bar{u} c$ or $c l \bar{u} c e$, following the paradigm of ME brōke < OE brūcan. The ancestor Germanic root would then be *klukka- or klukkôn- (whence OE clycc(e) $a n)$. Like the $M E D$ (s.v. clọke n.(2)), the $O E D$ notes the possible influence of the verb clicchen $(<\mathrm{OE}$ clyccan) on the palatalised forms. If we apply Occam's razor again - as we did with crosez - it would not be far-fetched to presuppose that the ME word clōke might have been adopted from another Germanic, nominal, root rather than assuming multiple unrecorded native developments and a word-class change (verb $>$ noun). Yet an ON cognate does not seem to have been identified either, only a surviving form in Swedish (see $M E D$, s.v. clọke n.(2), '?ON; cp. Sw klyka "a clamp, fork"). Sowmys 'chains or ropes' has multiple possible sources: not only ON (OIcel saumr 'nail, seam') but also AF (OF some, soume denoting a 'pack-saddle'), even if there are semantic differences which are left unexplained, ${ }^{31}$ an Anglo-Latin variant of LL sagma 'pack-saddle' (DMLBS, s.v. 2 salma, sauma, somma, suma, 1 summa) is also attested, which adds more complexity to the possible layers of influences that converged in the adoption of the ME word. The best semantic analogue, thus, seems to be the ON lexeme, and the supporting circumstantial evidence is here represented by the northern distribution of the word (cf. OED (1913), s.v. soam, n.; $M E D$, s.v. soume). As indicated in the Gersum database (s.v. stayned), steynedclothes 'worked in colours or embroidered clothes' - to be distinguished from stevynd, which in the DAR interestingly only co-occurs with Latin pannus/-i 'clothes' - can be semantically traced to two forms: ME stainen < aphetic version OFr desteindre 'to remove colour' or OIcel steina 'to colour, stain' (on the same root as steinn (OE stān)), whose semantic development is complicated but seems to bear resemblance to other Germanic languages (cf. OHG staimbort ?'painted shield'), including OE $\bar{a}$-stēenan 'to adorn (something) with precious stones' (DOE, s.v. $\bar{a}$-stōenan).

As Dance $(2013,2018,2019)$ fleshes out, the focus of this taxonomy is on etymological evidence and not on the outcome of contact. These two different ways of conceptualising ON input may interact in fruitful ways, but Dance's categorisation offers a more dynamic approach: the different types may encompass manifestations of language contact which would belong to different categories in traditional typologies (e.g. direct loanwords and loan shifts). Beyond structural evidence, other factors can come to play a role in assessing the etymology of a word. Dance brings to the fore two kinds of 'circumstantial' evidence, namely the Germanic distribution of a word in the form of cognates in closely related languages, represented by the West Germanic family (Middle Low German, Old and Middle High German, Middle Dutch, Old Frisian and Old Saxon) and the word's geographical distribution. The geographical

31 The $O E D$ ((1913), s.v. soam, n.) differs from the $M E D$ in hypothesising a borrowing from OF without mentioning $\mathrm{ON}$. 
confinement of a word to the north and the Danelaw area has often been identified as a marker indicating ON influence: while Björkman (1900) does consider a word's use as an auxiliary criterion, Miller (2012: 99) seems to go too far when claiming that this is 'the safest way to recognise a Scandinavian loan', especially if this distribution endures through time and still applies to Modern English. A correlation between such an important area of Scandinavian settlement and a greater incidence of ON input is not far-fetched and has indeed been demonstrated. ${ }^{32}$ The labels that Dance proposes to distinguish the kind of documentary evidence coming from the north or east of England are ' $b$ ' for toponymic recordings, and ' $c$ ' for the general lexis (see Dance 2019: I.62). Nevertheless, as Dance points out, the evidence adduced to claim ON influence based on geographical distribution is often contentious (2019: I.56-7). The context of use (e.g. in a literary text) and the size of the corpus examined are just a few of the factors that may skew the representativeness of the material employed if these are not properly accounted for. The Gersum project contains a few of the items in the $D A R$ database, but the context-dependent cues and semantic interpretation of them did not necessarily match that found in the DAR. This, for instance, applies to Type D2 sloknyng (B1 in the $D A R)^{33}$ and one Type CCC3 lexeme, bord, which cannot be among the ON-derived words because of its sense: rather than meaning 'table' (or derived meanings), senses which are rare in OE and may evince ON input (cf. ON bord), in the $D A R$ it always occurs in complex lexical units (e.g. in bordnayles) and has its prototypical meaning, which can be traced to OE bord.

Likewise, homographs within my database will also be kept distinct: band in hatband is OED (1885), s.v. band n. ${ }^{2}$ (from French), not the ON loanword (bandez, also in belybandes and dorebandez; see below). Arguably, a few more words than those classified into the different types show inputs from Scandinavian in various ways: for instance, saez $(\times 3)$ (also in watersay), another Scottish and northern term for 'a wooden tub', seems to derive from OE on the basis of the dating and contexts in which it is attested in early OE. Nevertheless, as the OED ((2015), s.v. sae, n.) remarks, the northern/eastern distribution of the lexeme and its ME variant soe possibly reflects ON-influx rather than an uninterrupted continuity with the native word. In the following section, I will overview the main semantic fields to which ON-derived lexis contributed within the multilingual lexical networks of the $D A R$ by using the Historical Thesaurus of the OED (HTOED).

32 See Kaiser (1937: 178-278), Xandry (1914), Thorson (1936), Kolb (1965) and Samuels (1985) on the 'Great Scandinavian Belt' and the more noticeable number of ON-origin grammatical words (Samuels 1985: 274-5; Dance 2003: 289-91). The results are dependent on the amount of the localised evidence surveyed, which was less accessible in the past than it is nowadays thanks to the online MED, LALME, LAEME (A linguistic atlas of early Middle English) and corpora.

33 Sloknyng is here considered Type B1 because 'le Sloknyng' (Rott. Bursar. 1488-9, 651) 'extinguishing' in the $D A R$ can be derived directly from $\mathrm{ON}$ (cp. Icel weak verb slokna 'to be extinguished'), whereas the meaning of slokes in Gawain is much more remote from its meaning in Scandinavian languages and, thus, more difficult to account for (see Gersum, s.v. slokes). 


\section{Semantic fields}

The relatively few ON-derived borrowings attested in OE before 1150 (c. 150, according to Kastovsky (1992: 321), and 185 relatively secure loanwords/expressions following Pons-Sanz (2013)) are mostly connected to cultural innovation or technological advancements, including sea-related terminology, warfare, law, currency, measures and, more generally, terms reflecting social or commercial exchanges (Durkin 2014: 180-1). The significantly larger numbers of Scandinavian-origin lexemes in Middle English, extant in a much wider range of text-types and registers, better allow us to assess the realms of Anglo-Scandinavian contact: not only were Scandinavian-specific or technical terms adopted and/or adapted into English but also basic lexical units used in everyday situations, sometimes already having synonyms in OE. ${ }^{34}$ The agents of lexical transfer would also have been substantially different pre- and post-1150: OE speakers would have been responsible for the early borrowings into OE, while possibly ON speakers, having switched to English, would have carried over later ON loanwords (see, inter alia, Townend 2002; Dance 2019). Apart from ON-origin simplexes, I have included complex lexical units - usually, $\mathrm{OE}+\mathrm{ON} / \mathrm{ON}+\mathrm{OE}$ constructions containing early Scandinavian lexemes (e.g. landmalebok 'a rent book'), some of which are quite recurrent in the DAR lexis ((h)aver, ${ }^{35}$ bag, cart, garth, girth, lyng, muk and wand. OE-origin words are also productively combined with ON elements (e.g. door in dorebandez, dorecrokez and dorestothez) and, more rarely, complex lexical units are made up of $\mathrm{ON}$ morphemes in their entirety, either (arguably) original compounds in Scandinavian (axiltre, blandcorne, stakgarth and wadmale) and, in two instances in my database, combined in ME (Scathaver and Cartfleykkes).

A significant proportion of the ON-derived vocabulary has to do with building, ${ }^{36}$ cultivation, ploughing, farming and animal husbandry. Equipment, either containers or tools represent 27 lexical items out of the total (160). I will now illustrate some of the most frequent categories under which these lexemes sit in the HTOED: ${ }^{37}$

- society » farming » animal husbandry » general equipment: belybandes 'bands which pass round the belly of horses', latbrodes 'goads', tedyr 'a tether' and sowmys 'trace-ropes';

34 Apart from the borrowing of new lexical material, the form, phonology or meaning of OE words was also sometimes remodelled to match the ON cognate (a well-known example of a process of phonological substitution in native material through contact is sister (cf. OE sweoster, swuster and OIcel systir) (see also in Gersum under half-suster and sister-sunes)).

35 Avermalts could also have been borrowed as a unit later on from another Germanic language, MLG hāvermolt (cf. earlier oat-malt). The $O E D$ ((2015), s.v. haver-malt $\mathrm{n}$.) dates its first attestation to 1569 , but it is attested two centuries earlier in the DAR (Rott. Bursar. 1388-9, 596).

36 Some names of materials also belong to this larger occupation domain of building (e.g. gaddis 'a metal bar or rod', flaggez 'flagstones' and wandes 'rods or sticks').

37 Some labels in the HTOED seemed to be unnecessarily complex (e.g. the categorisation of slaughter under 'the world » life » death » killing » killing of animals'), so I have adapted and simplified the categories for the purposes of this article. 
- equipment » building and constructing equipment » fastenings: broddes 'nails', linkis 'chains', spekys 'large nails', Sponbrod (pl.) 'nails for fastening shingles' and stanebrod 'a nail for fixing stone slates';

- equipment » receptacle or container (8 lexical items, 3 of which contain bag): among others, Bagsadle 'packsaddle', kagges 'small casks', ripp's 'baskets for fish', skepe 'a basket', skelez 'containers for liquids (milk, beer, etc.)' and stowpys 'jugs (also a measure for liquids)';

- farming » tools and implements » ploughing (or harvesting) equipment (3 containing crook): among others, Brercroke 'a hook for cutting brambles', Shepecroke 'a crook used in tending sheep' and hale 'a handle of a plough or wheelbarrow'. In addition, other terms (under different sections) are related to farming, namely, methods such as Rakyng and castyng, two instruments to prepare the soil, mukforkez, mukhak, ploughswaynlandes 'land cultivated by a plowman' and the measure unit thraff. ${ }^{38}$

Parts of machines and, especially, carts (a borrowing from $\mathrm{ON}$ itself) are also formed on ON lexical material (14 lexical items): including cart (cartbod, Carth'neys, cartrapes, cart sadyll, cartsadiltrees, cartsilver, cartstrakes, Langcart'), cod 'a bearing of an axle', cloukis 'clutches', axiltre 'an axletree' and axiltre hopez 'bands or hoops about the axletree'.

Names for animals in general and specifically for food (food and drink » food » animals for food) and in general, amount to 11 lexemes: Baghors 'packhorse', fish (Gedde, Kelinges and scates), a kind of bird (snypys), kydsape 'lice of sheep', hence, 'soap to destroy such lice', and brusket' 'the brisket of an animal'. Skin is also present in may skynnes, possibly 'the skin of a sheep or lamb slaughtered in May', as is the term slaughter, itself as a simplex, Slaughters, and in compounds (Slaughtermanhous and Slawghterhouse). Within the domain of food, there are cereals or grain (food and drink » food » corn, cereals or grain), blandcorne 'a blend of rye and wheat', Avergarner and haverbarne 'a storehouse for oats' and Coltehauer 'oats for colts'. Instruments involved in the production of dairy products (food » food manufacture and preparation " preparation of dairy produce) are Syle, milksyle 'milk strainer', chesefleke possibly 'a flake for storing cheese' and for the sifting of cereals, bygbern 'barley sieve'. Other representative semantic domains are the following:

- fees and taxes (trade and finance » fees and taxes » impost, due, or tax), landmale 'a rent on land' (and the aforementioned landmalebok), medowmale 'a tax on meadowland', Scathaver 'a tributary rent of oats', payments for hires or rents (trade and finance »" fees and taxes » hire or rent), gersuma 'a manorial rent' and Wandepenys 'customary rents';

- feudal services (authority » subjection » service » feudal service), bondis, Bonesilver 'boon work, an extra service required by a feudal lord of his tenant' and more generally, tolbothe 'a custom house';

${ }^{38}$ No other measures are attested in the $D A R$ as coming from $\mathrm{ON}$, only the measurement instruments scales, merowscales and Weyscill. 
- plants (plants » particular plants), brakennez 'a variety of ferns', Scrabbez 'crab apples' ('food plant'), Lyng 'heather', and the compounds lynghouse and lyngthake; places to store materials, animals, or to cultivate plants, including bernegarth 'a barn', Impgarth 'a garden where seedlings are cultivated', swynhousgarth and Wodegarth;

- natural phenomena or features of the landscape (under 'the earth' section of the HTOED, although scattered under different categories), dam, banke, kerr 'a marsh' and mosse.

Other miscellaneous lexical items include 'parts of a building' (inhabiting and dwelling » inhabited place » a building » parts of building), bandez 'hinges of a door', dorestothez 'doorjambs', gabell 'gable or façade of a building', wadmale 'a kind of woollen cloth' and other -ing forms (some related to building as well) such as drawkyng 'saturating with moisture, as flour or quicklime with water', flyttyng 'removing', kyrvynge 'carving', ryvyng 'splitting of wood' and wyndyng 'wattling, enclosing with wattle-work'.

It is worth noting that not all the ON-derived words are classified in the HTOED (only, e.g., the separate units in dorecrokez, eldyngpan, twhertsawes and windowclathe), and a few others are semantically tagged with a sense different from the one in the DAR (e.g. flywinges as either (a) the wing of a fly or (b) bookbinding (see quot.), OED (1897), s.v. fly-wing n. rather than with the figurative sense of 'some kind of small nail' (MED, s.v. flie n.(1), 3. (c) fle-wing, fli-)). Likewise, the two different kinds of borrowings preand post-twelfth century are present in the DAR (gersuma and male were already borrowed into OE) although other than those, there are not many cultural concepts. Rather, as expected given the nature of these rolls, vocabulary from everyday activities such as building, farming, ploughing and animal husbandry, including some specialised terminology for pieces, tools or instruments is the general trend of ON-derived lexical items in the $D A R$.

\section{Final remarks}

All in all, this article has concentrated on the challenges and opportunities in assessing the different kinds of evidence available for establishing the relative plausibility of a word being derived from $\mathrm{ON}$ in the $D A R$. It has drawn on Dance's taxonomy - Type A relying on formal (phonological, morphological, and phonological and morphological) features, and from Types B to D, the evidence is less secure in ascending alphabetical order - and applied it to the $D A R$ multilingual material, an enterprise which had not been undertaken beyond the analysis of monolingual English sources. This lexical compilation also brings to light the many ways in which scribes would express plurality irrespective of the language of origin of the morphological material involved (see, e.g., gonnys, gonnez, gun, Gonnis, Gunnis), which underscores the particularly permeable language borders found in ML texts produced by multilingual scribes.

The semantic distribution discussed in section 3 points towards several semantic subdomains (most notably equipment, either containers or tools) as being particularly prone to making use of vernacular, ON-origin, vocabulary. The data available are, however, conditioned by the scribes' expressive necessities and frequency of usage in 
their own vernaculars rather than by linguistic preferences based on extralinguistic reasons. Future research should further examine the $\mathrm{ON}$ input in other multilingual sources, thereby enriching our understanding of the complex interrelations between ML and the vernaculars in late medieval England.

Author's address:

University of Cambridge

Selwyn College

Grange Road

Cambridge CB3 9DQ

$U K$

adr41@cam.ac.uk

\section{References}

Björkman, Erik. 1900-1902. Scandinavian loan-words in Middle English, 2 vols. Halle: Max Niemeyer.

Brate, Erik. 1885. Nordische Lehnwörter im Orrmulum. Beiträgen zur Geschichte der deutschen Sprache und Literatur 10, 1-80, 580-6.

Campbell, Alistair. 1959. Old English grammar. Oxford: Clarendon Press.

Cercignani, Fausto. 1983. The development of */k/ and */sk/ in Old English. Journal of English and Germanic Philology 82, 313-23.

Cole, Marcelle. 2018. A native origin for Present-Day English they, their, them. Diachronica 35(2), 165-209.

Coleridge, Herbert. 1859. On the Scandinavian element in the English language. Transactions of the Philological Society 6, 18-31.

Dance, Richard. 2003. Words derived from Old Norse in early Middle English: Studies in the vocabulary of the south-west midland texts. Tempe, AZ: Arizona Center for Medieval and Renaissance Studies.

Dance, Richard. 2012. English in contact: Norse. In Alexander Bergs \& Laurel J. Brinton (eds.), English historical linguistics: An international handbook, 2 vols. Berlin: De Gruyter Mouton.

Dance, Richard. 2013. 'Tor for to telle': Words derived from Old Norse in Sir Gawain and the Green Knight. In Jefferson \& Putter (eds.), 41-58.

Dance, Richard. 2014. Getting a word in: Contact, etymology and English vocabulary in the twelfth century (The Sir Israel Gollancz Memorial Lecture 2013). Journal of the British Academy 2, 153-211.

Dance, Richard. 2018. The horns of a dilemma: Finding the Viking influence on medieval English vocabulary. In María José Esteve Ramos \& José Ramón Prado Pérez (eds.), Textual reception and cultural debate in medieval English studies, 101-28. Newcastle upon Tyne: Cambridge Scholars.

Dance, Richard. 2019. Words derived from Old Norse in Sir Gawain and the Green Knight: An etymological survey, 2 vols. Oxford: Philological Society.

Dance, Richard, Sara Pons-Sanz \& Brittany Schorn. 2019. The Gersum project: The Scandinavian influence on English vocabulary. Cambridge, Cardiff and Sheffield. www.gersum.org (accessed 27 May 2020).

$D M L B S=$ Latham, Ronald E., David R. Howlett \& Richard K. Ashdowne. 1975-2013. Dictionary of Medieval Latin from British sources. Oxford: British Academy. www.dmlbs.ox.ac.uk (accessed 27 May 2020). 
$D O E=1986-$ The dictionary of Old English: A-I. Toronto: Pontificial Institute of Medieval Studies. www.doe.utoronto.ca/pages/index.html (accessed 27 May 2020).

DOST $=$ Craigie, William A. et al. 1937-2002. Dictionary of the Older Scots tongue, 12 vols. Oxford: Oxford University Press. www.dsl.ac.uk (accessed 27 May 2020).

Durkin, Philip. 2014. Borrowed words: A history of loanwords in English. Oxford: Oxford University Press.

Durkin, Philip. 2016. The OED and HTOED as tools in practical research: A test case examining the impact of loanwords on areas of the core lexicon. In Merja Kytö \& Päivi Pahta (eds.), The Cambridge handbook of English historical linguistics, 390-406. Cambridge: Cambridge University Press.

Fowler, Joseph Th. 1898-1901. Extracts from the account rolls of the Abbey of Durham, from the original MSS, 3 vols. Durham: Surtees Society.

Gevenich, Olga. 1918 [1916]. Die englische Palatalisierung von $k>\check{c}$ im Lichte der englischen Ortsnamen. Halle: Max Niemeyer.

Haspelmath, Martin \& Uri Tadmoor (eds.). 2009a. Loanwords in the world's languages: A comparative handbook. Berlin: De Gruyter Mouton.

Haspelmath, Martin \& Uri Tadmoor (eds.). 2009b. World loanword database. Leipzig: Max Planck Institute for Evolutionary Anthropology. http://wold.clld.org (accessed 27 May 2020).

Hogg, Richard M. 1979. Old English palatalization. Transactions of the Philological Society 77, 89-113.

Hogg, Richard M. 1992. A grammar of Old English, vol. 1: Phonology. Oxford: Blackwell.

$H T O E D=$ Kay, Christian, Jane Roberts, Michael Samuels \& Irené Wotherspoon. 2009. Historical thesaurus of the Oxford English dictionary. Oxford: Oxford University Press. www.oed.com/ thesaurus (accessed 27 May 2020).

Ingham, Richard. 2009. Mixing languages on the manor. Medium AEvum 78 (1), 80-97.

Ingham, Richard (ed.). 2010. The Anglo-Norman language and its contexts. Woodbridge: York Medieval Press / Boydell \& Brewer.

Jefferson, Judith A. \& Ad Putter (eds.). 2012. Multilingualism in medieval Britain (c. 1066-1520). Turnhout: Brepols.

Jordan, Richard. 1974. Handbook of Middle English grammar: Phonology, trans. and rev. by Eugene Joseph Crook [Jordan-Crook]. The Hague and Paris: Mouton.

Kaiser, Rolf. 1937. Zur Geographie des Mittelenglischen Wortschatzes. Leipzig: Mayer \& Müller.

Kastovsky, Dieter 1992. Semantics and vocabulary. In Richard M. Hogg (ed.), The Cambridge history of the English language, vol. 1: The beginnings to 1066, 290-408. Cambridge: Cambridge University Press.

Kluge, Friedrich. 1901 [1891]. Geschichte der englischen Sprache (mit Beiträgen von D. Behrens und E. Einenkel). In Hermann Paul (ed.), Grundriss der germanischen Philologie, vol. 1 (2nd edn), 926-1151. Strassburg: Trübner.

Knigge, Friedrich. 1885. Die Sprache des Dichters von Sir Gawain and the Green Knight, der sogenannten Early English Alliterative Poems und De Erkenwalde. Marburg: Universitäts-Buchdruckerei.

Kolb, Eduard. 1965. Skandinavisches in den nordenglischen dialekten. Anglia 83, 127-53.

Kristensson, Gillis. 1976. A note on palatalization of Germanic $k$ in English. Studia Neophilologica 48, 321-4.

Krygier, Marcin. 2000. OE (non-)palatalized */k/: Competing forces of change at work in the 'seek'-verbs. In Irma Taavitsainen, Terttu Nevalainen, Päivi Pahta \& Matti Rissanen (eds.), Placing Middle English in context, 461-73. Berlin: Mouton de Gruyter.

LAEME = Laing, Margaret. 2013. A linguistic atlas of early Middle English, 1150-1325, 3.2. www.lel.ed.ac.uk/ihd/laeme2/laeme2.html (accessed 27 May 2020). 
LALME $=$ McIntosh, Angus, Michael L. Samuels \& Michael Benskin. 1986. A linguistic atlas of late mediaeval English, 4 vols. Aberdeen: Aberdeen University Press.

Lass, Roger, 1997. Historical linguistics and language change. Cambridge: Cambridge University Press.

Liberman, Anatoly. 2007. Palatalized and velarized consonants in English against their Germanic background, with special reference to i-umlaut. In Christopher M. Cain \& Geoffrey Russom (eds.), Studies in the history of the English language III. Managing chaos: Strategies for identifying change in English, 5-36. Berlin: De Gruyter Mouton.

Liberman, Anatoly. 2008. An analytic dictionary of English etymology: An introduction. Minneapolis, MI: University of Minnesota Press.

Luick, Karl. 1935. Zur Palatalisierung. Anglia 59, 273-86.

$M E D=$ Lewis, Robert E. et al. (eds.). 1952-2001. Middle English dictionary. Online edition in Middle English compendium. Ed. Frances McSparran et al. Ann Arbor: University of Michigan Library, 2000-18. http://quod.lib.umich.edu/m/middle-english-dictionary/ (accessed 27 May 2020).

Miller, D. Gary. 2012. External influences on English: From its beginnings to the Renaissance. Oxford: Oxford University Press.

Minkova, Donka. 2003. Alliteration and sound change in early English. Cambridge: Cambridge University Press.

Minkova, Donka. 2014. A historical phonology of English. Edinburgh: Edinburgh University Press.

Minkova, Donka. 2016. From stop-fricative clusters to contour segments in Old English. In Don Chapman, Colette Moore \& Miranda Wilcox (eds.), Studies in the history of the English language VII. Generalizing vs. particularizing methodologies in historical linguistic analysis, 29-59. Berlin: De Gruyter Mouton.

$O E D=$ Proffitt, Michael (ed.). 1990-in progress. The Oxford English dictionary, 3rd edn. www. oed.com (accessed 27 May 2020).

$O N P=A$ dictionary of Old Norse prose. 1985-. Copenhagen: Den Arnamagnæanske

Kommission. https://onp.ku.dk/onp/onp.php (accessed 27 May 2020).

Penzl, Herbert. 1947. The phonemic split of Germanic $k$ in Old English. Language 23, 34-42.

Pons-Sanz, Sara M. 2013. The lexical effects of Anglo-Scandinavian linguistic contact on Old English. Turnhout: Brepols.

Ringe, Don. 2004. Old English mapelian, maeplan, mēelan. In J. H. W. Penney (ed.), Indo-European perspectives: Studies in honour of Anna Morpurgo Davies, 417-35. Oxford: Oxford University Press.

Roig-Marín, Amanda (forthcoming a). On the Latin-Romance continuum in the Durham Account Rolls. Zeitschrift für romanische Philologie.

Roig-Marín, Amanda (forthcoming b). Northern Middle English spelling evidence in the Durham Account Rolls.

Samuels, M. L. 1985. The great Scandinavian belt. In Roger Eaton et al. (eds.), Papers from the Fourth International Conference on English Historical Linguistics, 269-81. Amsterdam: John Benjamins.

Skeat, Walter W. 1882. Etymological dictionary of the English language. Oxford: Clarendon Press.

Steenstrup, Johannes C. H. R. 1882. Normannerne, vol. 4: Danelag. Copenhagen: Klein.

Thorson, Per. 1936. Anglo-Norse studies: An inquiry into the Scandinavian elements in the Modern English dialects, part I. Amsterdam: Swets and Zeitlinger.

Townend, Matthew. 2002. Language and history in Viking Age England: Linguistic relations between speakers of Old Norse and Old English. Turnhout: Brepols.

Trotter, David A. (ed.). 2000. Multilingualism in later medieval Britain. Cambridge: D. S. Brewer. 
Trotter, David. 2003. Oceano vox: You never know where a ship comes from. On multilingualism and language-mixing in medieval Britain. In Kurt Braunmüller \& Gisella Ferraresi (eds.), Aspects of multilingualism in European language history, 15-33. Amsterdam: John Benjamins.

Trotter, David. 2009. 'Stuffed Latin': Vernacular evidence in Latin documents. In Jocelyn Wogan-Browne, Carolyn Collette, Maryanne Kowaleski, Linne Mooney, Ad Putter \& David Trotter (eds.), Language and culture in medieval Britain: The French of England c.1100 c.1500, 153-63. York: York Medieval Press / Boydell \& Brewer.

Trotter, David. 2010. Bridging the gap: The (socio)linguistic evidence of some medieval English bridge accounts. In Ingham (ed.), 52-62.

Watson, John W., Jr. 1947. Non-initial $k$ in the north of England. Language 23: 43-49.

West, V. Royce. 1936. Der etymologische Ursprung der neuenglischen Lautgruppe [sk].

Anglistische Forschungen 83. Heidelberg: Winter.

Wright, Laura. 1992. Macaronic writing in a London archive, 1380-1480. In Matti Rissanen, Ihalainen, Ossi Nevalainen \& Terttu Taavitsainen (eds.), History of Englishes: New methods and interpretations in historical linguistics, 762-70. Berlin: Mouton de Gruyter.

Wright, Laura. 1995. A hypothesis on the structure of macaronic business writing. In Jacek Fisiak (ed.), Medieval dialectology, 309-21. Berlin: Mouton de Gruyter.

Wright, Laura. 1998. Mixed-language business writing. Five hundred years of code-switching. In Ernst Håkon Jahr (ed.), Language change: Advances in historical sociolinguistics, 99-118.

Berlin: Mouton de Gruyter.

Wright, Laura. 2002. Code-intermediate phenomena in medieval mixed-language business texts. Language Sciences 24 (3-4), 471-89.

Wright, Laura. 2010. A pilot study on the singular definite articles le and la in fifteenth-century London mixed-language business writing. In Ingham (ed.), 130-42.

Wright, Laura. 2011. On variation and change in medieval mixed-language business writing. In Herbert Schendl \& Laura Wright (eds.), Code-switching in early English, 191-218. Berlin: De Gruyter Mouton.

Wright, Laura. 2012. Mixed-language accounts as sources for linguistic analysis. In Jefferson \& Putter (eds.), 123-36.

Wright, Laura. 2017. On non-integrated vocabulary in the mixed-language accounts of St Paul's Cathedral, 1315-1405. Proceedings of the British Academy 206, 272-98.

Xandry, Georg. 1914. Das skandinavische Element in den neuenglischen Dialekten. NeuIsenburg: A. Koch.

Appendix. List of ON-derived lexis in the $D A R$ alphabetically ordered by the ON-derived stem (in bold) and according to the type of evidence available

A1

broddis, brodnales, latbrodes, latbroddes, Sponbrod, stanbrod, stanebrod, stanebrod', stanebroddez, staynbroddes, Strabrod

bygbern (le), Bygbarne (le)

castyng (le)

drawkyng (le)

Rent Egges, renthegges, Rentges

Sponegarn

bernegarth, ympgarth (vocati), Impgarth (le), swynhousgarth (le), connyngarth (le), cunyngarth (le), Stakgarth (le), stakgarth, stakgarthez (lez), Wodegarth

gersuma, gersumis 
girthys, girthes, girthez, gyrthes, gyrthis (le), girthbukyls, gyrthbokeles, girthbokyls, girthbukles, Girthwebbs, gyrthwebbez, girthweb, girthwebb', girthwebbes, gurthwebbis, gyrthwebs, Girthetres

gonnys, gonnez, gun, Gonnis, Gunnis

kerr

keruyngknyves, kirvyngknyffes (del), kirvyngknyffez (le), kyrvyngknyffez (lez)

kydsape

kyrn, kyrnez, kyrne (le), kirne, kirn

landmale, landmall, layndmayle, landmale, landmalebok (le), medowmale

lyttynglede, littyngleyde

scale (pl.), Scalez, Skalez, merowscales, Weyscill, Weyscalez (del)

scappes, skepe, Skeppys, skeppez, Skeppez (les), scepys, skeppis, skepis

scates, Schat, Scathaver, Scatmaltez, Scaltmaltes

skelez, skelys, skeyllys, skelys (le), skeles, schele

skers

may skynnes, whiteledirskynnes

stowpys, stowpes, stopez, stopis, stoppes, stopys, stowpez

ploughswaynlandes

windowclathe, wyndowclath

Hempyard (le), Wodyard, Wodeyard (del), Wodyard (le), Wodyarde (le), Wodyard (del), ymppeyard (le), ympyard

A2

twhertsawes

B1

aughtyndel, aughtindel, Auzghtindel, Agktyndell anguill., aghtendell, Aghtyndell (pl.)

bandez, bandis, belybandes, dorebandez, doorbandez, bondis

barkhous

brakennez (lez)

eldyngpan

flaggez (lez), flagez (del/lez), flagges, flaggyng

flaxstons

Gedde

hale

hanyng (le)

Kelinges, kelyngs, keling, kyling, keling'

Lyng, lyngelaund (le), lynghouse, lyngthake (del)

mukforkez, muk fork, mukhak, mukhakkys, mukhakkez

rove

Scrabbez, Scrabbez (lez)

Sloknyng (le) 
Staikes (le), stakes (del), stakez, stakez (le/lez), Stake (le), stakgarth (le), Stakgarth, stakgarthez (lez)

staures, stoowrys, stowrys, dalbyngstoures, dalbyngstourez, dalbyngstowres, dalbyng stowres, dalbyng stowris, dalbyngstowrys, doubyngstoures, hekstaures, rungstoures

Syle (vocata), milksyle

thraff, thrave, thraves, thrawe, thrawez, thravis, threff

toft., tofto, toft

wadmale

flywinges

B2

Scathaver (vocatur)

bag, bagges, Bagsadle, bagsadiltres

banke (le)

bothis, bothe, boyth (le), tolbothe (le), Tolboth (le)

Cob Iryns

crokez, crokes, crokys, crokis, croke, crok, crukkis, crukys, cruke, cruk, crukkis,

Brercroke, dorecrokez, Shepecroke, Shepcroke

dam (le), dampe [sic]

flakes, fleke, flekes, flekys, scaffalde flakes, chesefleke (cf. Cartfleykkes)

gabelorum, Ganeyls [Fowler's note: read gauelys], gabellorum, gabell, gabali, gavill (le), gavill, gawellez

gaddis

haverbarne (le), Avergarner (le), Havergarner (le), havermaltes, Averpenys, Haverpennez, Coltehauer, Colthaver, colthelter

kagges

keruyngknyves, kirvyngknyffes (del), kirvyngknyffez (le), kyrvyngknyffez (lez)

linkis

ripp's

ryvyng (le)

snypys

tedyr, teder, tethirdez, tethyr

wyndyng

C1

Bonesilver

flyttyng (le)

hyngynges (lez)

croceloft

slawters, Slaughters, Slawghterhouse (le), Slaughterhouse (le), slaughterhouse (le), slaughterhous (le), Slaughterhows (le), Slawghterhosse, slawghterhouse, Slaughtermanhous, Slawghtermanhows, slawghterman housse, Slaughtermanhowse wandes, wandys, Wandepenys, wandpenis, Wandpenys, Saylwandis, Saylwandes 


\section{C2}

Cartbod., cartbodyes, Cartfleykkes, Carth'neys, Carteharnas, cartharneyse, cartrapes, Carterapis, Carterapes, cartropez, kartrapes, Cartesadle, Cartesadyll (le), cartsadiltrees, cartsilver, Cartstrakes, Langcart', Stankart (le)

stothes, dorestothez, dorestothis (le), dorstothez

C3

bollez

coddis

ferybote (le), ferybott

mosse, mosse (le), mossez (le)

Sponbrod, sponyarn

thyxtyll goug

C4

axiltre, axiltreys, axiltres, axhiltriss, axyltres, axiltre hopez (see also axilnayl (pl.), axillyng')

blandcorne

C5

crosez (lez)

D1

cloukis

sowmes

stevynd, stevynd, steynedclothes 